\title{
Uma Visita ao Barão
}

\author{
Carlos Osmar Bertero \\ Tatiana Iwai
}

\section{RESUMO}

A figura do Barão de Mauá ocupa lugar de indiscutível destaque no desenvolvimento econômico do Brasil. Sua trajetória é largamente analisada não apenas pelas importantes realizações que promoveu, mas também porque se tornou símbolo de um empreendedor, cuja falência dos negócios é freqüentemente debitada a um contexto institucional, que não soube entender sua visão de desenvolvimento para o país e foi hostil a seus projetos de industrialização e modernização do Brasil. No entanto, se revisitarmos sua trajetória, veremos que não apenas suas ações empresariais podem ser consideradas equivocadas, se analisadas à luz dos atuais conceitos desenvolvidos na área de estratégia, como também guardaram certa intimidade com a política governamental da época. Dessa maneira, Mauá foi, em certo grau, prisioneiro do contexto institucional brasileiro do período. Nesse sentido, o objetivo deste artigo é rever a posição de que Mauá, como empreendedor do tipo clássico, opôs-se à ordem institucional vigente e, por isso, teria sido punido. Na verdade, veremos que, se ele se opôs a essa ordem, nela também confiou e passou a dela depender.

Palavras-chave: empreendedorismo; estratégia; institucionalismo.

\section{ABSTRACT}

The towering figure of the Baron of Mauá holds an indisputable place in the economic development of Brazil. His trajectory is widely analyzed not only because of his important achievements, but also because he became the symbol of an entrepreneur, whose failure in business is often blamed on an institutional context that could not understand his vision of development for the country and was hostile towards his industrialization projects and modernization of Brazil. Nevertheless, if we review his trajectory, we will see that not only can his actions in business be considered mistaken, if analyzed in the light of current concepts developed in the field of strategy, but they were also close to the governmental policies of the time. Therefore, to a certain extent, Mauá was a prisoner of the Brazilian institutional context of his day. The aim of this article is to review the position that Mauá, as a classic-style entrepreneur, was opposed to the institutional order of his day and, for that reason, would have been punished. We will actually see that on the one hand, he was opposed to it, and on the other he also trusted it and came to depend on it.

Key words: entrepreneurship; strategy; institutionalism. 


\section{INTRODUÇÃO}

A importância de Irineu Evangelista de Sousa, mais conhecido como Barão de Mauá, para o desenvolvimento econômico do Brasil deixa margem a poucas dúvidas. Banqueiro, industrial, comerciante, fazendeiro e político, seu nome está associado à construção da primeira ferrovia no país. Foi também pioneiro no estabelecimento da primeira fundição, na iluminação do Rio de Janeiro, na navegação de cabotagem no Amazonas e na viabilização do primeiro cabo submarino, ligando o Brasil à Europa e, desse modo, possibilitando a comunicação via telégrafo.

No entanto, tão impressionante como suas realizações e o vasto império que construiu foi o crepúsculo e o final de sua carreira empresarial. Para que se possa aquilatar a realização, no seu apogeu, ocorrido ao redor de 1867, o valor total dos seus ativos contabilizava 115 mil contos de réis, quando o orçamento do Império de D. Pedro II, era de 97 mil contos de réis.

Em 1877, após quase 30 anos de empreendimentos, Mauá teve sua licença de comerciante cassada como resultado da decretação de falência de seus negócios, porque não conseguiu que o governo renegociasse as dívidas, que vinha lutando para saldar desde a declaração da moratória da Mauá e Cia. 3 anos antes.

$\mathrm{Na}$ época da falência, o Barão redigiu o texto Exposição do Visconde de Mauá aos Credores de Mauá e Cia. e ao Público (MAUÁ, 1996). Relata a trajetória de seus principais empreendimentos, bem como analisa as causas que o levaram à falência. Dizia esperar que outros não viessem a sofrer os dissabores que ele havia sofrido nas mãos dos dirigentes do seu país. Ficava implícito que as causas para seu fracasso não se deviam necessariamente a alguma imprevidência sua ou falta de capacidade gerencial no manejo e na condução dos seus negócios, mas resultaram de uma postura indiferente e, muitas vezes, hostil do governo em relação às suas iniciativas.

Mauá sublinhava o papel institucional do Estado na condução de políticas públicas e o impacto negativo que a intromissão governamental, em certas esferas, pode causar em iniciativas empreendedoras, visando ao desenvolvimento econômico do país. Desse modo, a história de Mauá se tornou um símbolo a ser lembrado de políticas governamentais incongruentes e de uma postura pouco propícia ao desenvolvimento de negócios, cujos objetivos não deixavam de ser a promoção do bemestar comum.

De fato, o ambiente institucional existente na época dos empreendimentos do Barão, que abrangeu desde 1840 até meados de 80 , quando ele finalmente teve sua licença de negociante cassada, não pode ser considerado exatamente um convite a empreendimentos industriais. Envolvia uma política econômica de restrição ao crédito, um cenário político de manutenção de antigas estruturas mercantilistas e judiciário ineficiente, atrelado ao antigo clientelismo colonial.

O livro escrito por Jorge Caldeira (1995), no qual este artigo foi em boa parte inspirado, tomando-o como referência e ponto de partida, ilustra muito bem esse contexto. No livro, Caldeira nos apresenta Mauá contra o pano de fundo do Império brasileiro, já que as datas do barão coincidem praticamente com a do período imperial de nossa história. Chega ao Rio de Janeiro como menino caixeiro pouco antes da proclamação da independência, falecendo três semanas antes da proclamação da república. Caldeira chega a fazê-lo, por vezes, contracenar com D. Pedro II, como se um representasse o Império com as características institucionais que adiante exploraremos, enquanto Mauá é alguém fora do mainstream imperial. Chega a rivalizar com o imperador, sendo seu vizinho, com seu palácio ao lado do imperial em São Cristóvão. Além disto, Mauá aparece como dotado de um talento empreendedor que seria diverso daquilo que se poderia esperar do nosso império. Afinal, a elite imperial brasileira aparece como ligada a uma ordem econômica rural e escravocrata, e aspirando a ocupar cargos na administração pública imperial. Nadando contra a corrente e afastando-se dos caminhos que a elite imperial habitualmente trilhava, Mauá vai construindo o seu império, diverso do de Pedro II. Enquanto o imperador tecia e construía uma ordem política e institucional aparentemente mantenedora do statu 
quo, Mauá tentava criar um Brasil mais próximo das tendências do século XIX europeu e norte americano. A acumulação se faria através da industrialização, da iniciativa privada e do trabalho assalariado, características de uma ordem capitalista moderna.

Nosso intuito é de rever parcialmente estas posições, mostrando que a excepcionalidade do barão é inegável, porém não tão extensa. Nalguns aspectos ele conflita com a ordem institucional de nosso Império, mas também, como não poderia deixar de ser, é marcado por esta mesma ordem que auxilia na explicação de seu sucesso e também de seus fracassos, que não foram poucos. A explicação do Empresário do Império pode enriquecer-se, se o analisarmos enquanto empreendedor fazendo uso de conceitos atuais desenvolvidos na área de estratégia empresarial, analisando até que ponto foi capaz de montar um grupo empresarial consistente e que poderia ser considerado estrategicamente coerente.

Neste artigo, primeiramente, mostra-se a importância de inserir na discussão da estratégia aspectos institucionais que cercam a ação organizacional e sublinhar a contribuição que uma perspectiva institucional pode prover aos estudos de estratégia. Em seguida apresenta-se o contexto institucional do período, marcado por uma economia de vocação agrária, uma sociedade basicamente escravista, uma monarquia conservadora, com poder centralizado pelo imperador, pela ausência de mercado financeiro estruturado e, por fim, por uma mentalidade cujos interesses privados não convergiam para o bem comum.

Em seguida, analisam-se as estratégias adotadas pelo Barão nos seus negócios. Constata-se que a lógica de seus negócios, bem como o histórico de decisões, evidenciam não só ações empresariais equivocadas, a partir do que hoje sabemos sobre estratégia, como também não se opôs radicalmente à política governamental da época.

\section{A Perspectiva Estratégica}

O desenvolvimento da área de estratégia foi até o momento marcado por uma abordagem predominantemente econômica, o que acabou significando a colocação da estratégia no universo da racionalidade. As perspectivas do posicionamento, da dependência de recursos e dos custos de transação fazem uso de uma racionalidade formal, prescindindo das variáveis espaciotemporais. Não importa onde, quando e o que se decida. As decisões serão sempre as mesmas, desde que se tenham adequado aos princípios da racionalidade estabelecidos e consagrados na análise econômica. A estratégia explica-se em função de variáveis e critérios que são os da análise econômica e é dotada de universalidade.

A percepção da importância da abordagem institucional em estratégia vem sendo desvendada mais lenta e recentemente. Algumas perspectivas podem conter indicações de elementos institucionais, como a abordagem cultural e a da estratégia enquanto poder e negociação, como apontadas por Mintzberg (1998). Mas há que considerar que muitas das estratégias adotadas só encontram explicação dentro de um contexto institucional, ou seja, quando se leva em consideração a história, as instituições, a cultura, e o contexto legal das sociedades em que as estratégias são formuladas. Não é possível negar o importante papel que o mimetismo desempenha na formulação e adoção de estratégias, especialmente nos ramos oligopolizados, onde constatamos que há uma única estratégia adotada por diversos players que integram o mesmo grupo estratégico.

A importância do institucionalismo já vem sendo enfatizada nos domínios da própria economia. $\mathrm{O}$ tratamento de questões econômicas, apenas em termos de análise econômica, vem encontrando restrições, na medida em que se dá ênfase a outros fatores, como a cultura, o passado histórico e o contexto institucional em que a atividade econômica acontece. A afirmação de que o desenvolvimento ou crescimento econômico está relacionado com a cultura de um povo já de há muito é aceita, o que explica o fato de o capitalismo ter ocorrido na cultura ocidental e não noutras culturas. A universalização de uma economia de mercado em nossos dias ainda é marcada por interrogações. E 
estas são predominantemente de natureza que chamaríamos de um contexto institucional. Até que ponto o quadro institucional não só resiste a uma economia de mercado, mas pode mesmo ser avessa a ela, impedindo que seja adotada?

Estas considerações justificam que se estendam à estratégia as mesmas indagações e se questione qual o papel do contexto institucional na formulação e adoção de estratégias. Trabalhos recentes (FLIGSTEIN, 2001) mostram como certos movimentos estratégicos não encontram explicação, se não incluirmos uma perspectiva institucional. $O$ caso da adoção de estratégias generalizadas de diversificação nos Estados Unidos nas décadas imediatamente posteriores ao final da Segunda Guerra Mundial se explicam também pela existência e aplicação de uma legislação antitruste, que dificultava a criação de diversificação downstream e upstream, deixando como alternativa a adoção de uma diversificação que se adequasse à concepção da empresa como portfolio de negócios, resultando numa estratégia de diversificação, que envolvia diversos ramos não necessariamente relacionados e que poderia, no limite, chegar, como nalguns caso se chegou, à criação de conglomerados.

Em nosso país, podemos pensar em várias situações em que a aplicação de uma perspectiva institucional seria necessária à explicação de movimentos estratégicos. Até que ponto as transformações que se registraram no ramo bancário, quando o negócio bancário se altera substancialmente, poderiam ser explicadas sem alterações na legislação e a criação de um novo contexto regulador, com a Lei de Reforma Bancária de 1964 e a criação do Banco Central? Até então o negócio bancário era entre nós uma atividade de pequenos e médios bancos. Mesmo os grandes bancos não seriam, pelos padrões atuais, mais do que pequenos estabelecimentos e desprovidos de qualquer caráter nacional. Eram apenas bancos regionais e isto se aplicava aos principais bancos de então que eram os paulistas, os cariocas e os mineiros.

Ainda em nosso país, quando se olha para o grande surto de crescimento, que caracterizou a economia brasileira desde o final da Primeira Guerra Mundial até o final da década de setenta, constatamos que não poderíamos explicá-lo sem recorrer às alterações no quadro institucional. Mudanças na legislação, criação de agências de fomento, alterações no sistema tributário, alterações na política comercial e industrial etc. Não se abandonou a agenda de preocupações de muitos, isto é, a questão da criação de uma política industrial. Claramente isto significa coisas diversas para diferentes atores. Mas todos lembram que o país possuía uma política industrial até o final da década de setenta. Esta se foi esgotando, o que se pode perceber através de vários indicadores. Em seu lugar nada de equivalente foi até o momento colocado. Sempre houve e há os que reclamam disto. Quando se discute a criação de zonas e acordos de comércio, como Mercosul e atualmente a gestação da ALCA, se está discutindo também a criação de um contexto legal em que as estratégias das empresas se inserirão. No limite, serão forçadas a levá-lo em consideração, por ocasião de suas revisões e formulações de estratégias.

Estas questões sobre o contexto institucional e a estratégia são identificáveis, quando se constatam diferenças em estratégias empresariais em países diferentes. O trabalho já referido de Neil Fligstein (2001) mostra como a governança corporativa e a concepção de sociedade anônima diferem nalgumas nações capitalistas ricas, Estados Unidos, Alemanha, França, Japão e Reino Unido. O autor sustenta que o movimento de Fusões e Aquisições, que assumiu enorme importância nos Estados Unidos a partir do final da década de setenta e se estende até os dias atuais, não aconteceu nos demais países, com a possível exceção do Reino Unido, mais semelhante aos Estados Unidos. Isto se deveria ao fato de que a concepção de sociedade anônima, e do que seja uma grande empresa, vigente nos Estados Unidos, por razões históricas e institucionais, não existe nos outros países estudados, particularmente Japão, França e Alemanha. Nestes, a história, a cultura e as tradições, que se refletem na cultura das organizações empresariais, não gerariam as condições para um grande movimento de fusões e aquisições semelhante ao que vem ocorrendo nos Estados Unidos.

O Brasil só pode ser explicado como parte de um império colonial português. A tentativa de se olhar o Brasil como colônia no contexto amplo do império português, com ligações profundas com as colônias africanas de Portugal, durante o período de formação colonial (ALENCASTRO, 2000; BOXER, 2002), tende a produzir explicações mais satisfatórias sobre nosso passado e que auxiliam no 
entendimento de nosso presente. O país independente emerge de um contexto colonial que conserva traços econômicos e instituições sociais, como a escravidão, fundamentais para o país. Isto nos parece justificar um levantamento do quadro institucional do Império para a devida contextualização do empreendedorismo de Irineu Evangelista de Sousa.

\section{O CONTEXTO INSTITUCIONAL DO IMPÉRIO}

O contexto institucional do Império brasileiro não pode ser entendido como conducente a um empreendedorismo que fosse contemporâneo ao que ocorria nos países que se industrializavam na Europa e com os Estados Unidos. O tema do anacronismo brasileiro é um leit motiv bastante difundido na nossa historiografia e nas ciências sociais. Euclides da Cunha, com seu clássico Os Sertões (2002), vê nele o elemento fundamental para explicar o fenômeno do messianismo do Arraial de Bom Jesus. Importante discussão que se trava a partir da segunda metade do século XIX é o debate sobre a industrialização (LUZ, 1961). Os Estados Unidos já surgiam, na segunda metade do século XIX, como saliente entre as novas nações americanas, recentemente independentes, que haviam deixado os vínculos dos impérios inglês, português e espanhol. Traço importante no perfil econômico do também jovem país era seu avanço na trilha da industrialização. Questionava-se então se a industrialização seria uma vocação brasileira ou se o país deveria seguir sua natural vocação agrária. $O$ debate finalmente termina em 1876, com a promulgação da Lei de Similares pela princesa Isabel, então no trono, devido a uma viagem de seu pai ao exterior, o que assegurava a resposta de que a industrialização não era pelo menos algo a ser evitado, como desejavam os partidários da vocação agrária. Para eles, a Lei de Similares poderia provocar uma industrialização artificial. Mas a lei foi promulgada e foi importante documento, mais útil à República do que o foi durante o período imperial.

No quadro institucional do Império ressaltaremos a importância do regime monárquico e a centralidade do imperador, as características do modelo econômico, o perfil da elite imperial, a ausência de um mercado financeiro mais desenvolvido e estruturado, as restrições à livre iniciativa e as comparações com o quadro institucional dos Estados Unidos.

A) O Brasil, ao tornar-se independente, adota um regime estranho para o hemisfério, a monarquia. Herança do próprio processo como a independência aconteceu, a colônia tendo-se desligado da metrópole por rebeldia do príncipe regente e que nunca deixou de contemplar uma reunificação com Lisboa, pelo menos com sua presença em ambos os tronos. Adotamos, em conformidade com o liberalismo político do início do século XIX, o modelo da monarquia constitucional, em que o imperador deveria conviver com um poder legislativo de alguma forma eleito e que representaria a nação. A constituição de 25 de março de 1824 , que nos regeu até a promulgação da republicana de 1891, estabelecia quatro poderes: o legislativo, o judiciário, o executivo e um quarto poder, o moderador. O executivo e o moderador eram exercidos pelo imperador. Atos adicionais, que emendaram com Pedro II a carta de 1824, acabaram por criar um presidente do gabinete que, na verdade, era um primeiro ministro, mas sempre como preposto do imperador. Ao monarca caberia constitucionalmente a plenitude do poder executivo. O moderador conferia ao Imperador centralidade absoluta no sistema e permitiu que exercesse papel fundamental na formatação das instituições políticas do novo país.

A imagem, até hoje predominante, de que o Império foi caracterizado por maior estabilidade institucional do que a tumultuada república, deve-se à centralidade do imperador, que manipulou com grande competência as elites políticas e fez a dança de gabinetes entre liberais e conservadores adquirir a monotonia freqüentemente encontrada em nossa historiografia do período imperial. O texto de Jorge Caldeira ressalta bastante o papel central do imperador, como criador, mantenedor e operador de um sistema e de um jogo político em que as coisas tendiam mais à permanência do que à mudança. O trabalho recente de Lilia Schwarcz (1998) deixa clara a importância do imperador como representante do Império Brasileiro e como levou a sério tal papel. Afinal, suas viagens internacionais, 
especialmente sua presença na Feira Industrial de Paris de 1867, estavam ligadas à promoção e divulgação deste estranho Império nos trópicos, onde o imperador, impecavelmente vestido com trajes europeus, carregava um manto imperial verde e amarelo. Pelas fotos que nos chegaram tinha pouco de seu pai, exibindo mais no fenótipo a etnia austríaca de sua mãe. Nosso exotismo tem raízes.

D. Pedro II era homem erudito, sofisticado, europeizado e possivelmente de identidade confusa. Resumindo, era um brasileiro. Via-se como europeu, apreciava Wagner, adorava ciência e tecnologia, seria um liberal e, no fundo, até um cético com relação ao futuro da instituição monárquica que via fenecer na própria Europa, onde as repúblicas começavam a se estabelecer. Mas daí não se pode inferir que não convivesse bem com as singularidades brasileiras, que pouco tinham a ver com todas estas características européias já mencionadas. Não se pode dizer que fosse, na sua ambivalência, um proponente ou um incentivador de um modelo econômico liberal capitalista na segunda metade do século XIX. Conviveu com a escravidão, com uma ordem agrário-exportadora, com um estado centralizador e clientelista, cujo patrimonialismo ajudou a construir pela trama entre participação política e ocupação de cargos na burocracia imperial. Tudo isto mostra que o Brasil não começou hoje, vinha assim de algum tempo.

B) O modelo econômico do período imperial, em grande medida, foi caracterizado e descrito pelos clássicos de nossa historiografia econômica (FURTADO, 2003; PRADO JUNIOR, 1976; SIMONSEN, 1978). Pouca alteração ocorreu com relação ao modelo colonial que serviu para nossa inserção no mundo econômico europeu e ocidental, como colônia agrário-exportadora, o que os ingleses chamariam plantation economy. Exportações centradas num único item de exportação, o que permitiu que nossos historiadores falassem em ciclos econômicos. O país se torna independente sem estar num pico econômico, mas antes num vale. Apenas lentamente o café se firmará como produto principal de nossas exportações, que não encontraram, por muito tempo, um substituto para o açúcar de cana, que não conseguira manter competitividade diante dos novos produtores do Caribe.

A industrialização se encontrava ausente do horizonte, em parte devido à fixação no modelo agrário exportador e sem grande atenção para as potencialidades de um mercado interno e em parte pela herança vinda do período colonial, que nos impedia a industrialização por força do Tratado de Methuen, celebrado entre Portugal e Inglaterra no início do século XVIII.

A isto se acrescente a importância da escravidão como instituição decisiva em nossa formação social. Embora a escravidão tenha ocorrido em diversos países das Américas, no Brasil, assumiu especial importância. Quando nos tornamos independentes, de uma população de aproximadamente 4,2 milhões de habitantes, estima-se que cerca de 3.0 milhões eram formados por negros escravos. A escravidão, entre nós, permeou não apenas a vida nos engenhos e fazendas de café e algodão, mas acabou por estender-se à vida urbana. A cidade do Rio de Janeiro teria mais escravos no ano de 1870 do que Roma na época de César Augusto. E isto só terminou com a Lei Áurea em 1888, quando no Atlântico Norte se iniciava a Segunda Revolução Industrial e o trabalho assalariado na Europa e na América do Norte já levara à formação de grandes sindicatos de empregados.

A escravidão criou um tipo de sociedade incompatível com os valores da cultura ocidental moderna, vide as dificuldades e as seqüelas geradas em todos os países que a tiveram. Além dos problemas de integração dos ex-escravos como cidadãos numa sociedade livre, ainda há as conseqüências puramente econômicas. Ressalte-se a inibição de um mercado interno pela ausência de massa salarial, a dificuldade em desenvolver mão de obra que tenha as habilidades e qualificações demandadas por uma economia industrial e o envolvimento de parte substancial da atividade comercial e financeira com o tráfego negreiro. Entre as razões para que a escravidão se prolongasse entre nós, apesar das pressões internacionais, especialmente as vindas da Inglaterra, há que adicionar o envolvimento das elites não apenas no uso de escravos como mão de obra em suas propriedades, mas como comerciantes. $\mathrm{O}$ escravo significava um bom investimento e sua rentabilidade, apesar das precárias condições de saúde, alimentação e higiene, que resultavam numa esperança de vida próxima dos 30 anos, ainda era das mais elevadas, sendo considerada superior àquela que se obteria nessa época no mercado financeiro londrino. 
C) A questão a natureza da elite brasileira coloca, no processo político e econômico do Império, pode ser entendida como o resultado de uma formação também herdada da colônia. Quando se fala de elite aqui, não nos referimos às elites provinciais, mas da que se concentrou na Corte, ou seja, na cidade do Rio de Janeiro. A elite política e econômica tinha duas bases de sustentação que poderiam mesclar-se e freqüentemente se mesclavam: a propriedade fundiária e o Estado, através de cargos na administração pública ou pelo clientelismo pelo qual se usava o poder e os recursos do Estado para o atendimento de interesses privados.

Já se mencionou que, em comparação com os Estados Unidos, nossa elite não possuía uma "moral do trabalho" (MOOG, 1957). Seriam ecos de Max Weber? De qualquer forma, o empreendedorismo, corolário desta moral do trabalho mais ligada à burguesia e ao puritanismo, não foi marca desta elite, mais voltada ao exercício do poder político e à ocupação de espaços na maquinaria administrativa do Estado. As origens desta elite são predominantemente rurais, pois se liga à propriedade fundiária, onde se encontrava quase exclusivamente a economia do país, mas também às origens de nossos quadros administrativos do serviço público. A administração pública imperial é herdeira da administração colonial portuguesa, cujos cargos públicos eram recompensas ou prebendas por apoio político. $\mathrm{O}$ monarca português centralizou seu poder, tornando uma nobreza feudal em nobreza de corte, apoiado na concessão de benesses e prebendas na burocracia do Estado. E esta tendência continuou no país depois que se tornou independente e somos tentados a dizer que persiste até os dias atuais. O fascínio de nossas elites pelo Estado é fantástico. Vide a facilidade com que elites empresariais, intelectuais e sindicais abandonaram e continuam abandonando suas posições para migrarem para o Estado.

A atração pelo Estado, pela carreira política, pela posição na burocracia estatal fez com que o empreendedorismo acabasse sendo mais característica dos excluídos, ou seja, dos imigrantes. O surto brasileiro de empreendedorismo, do final do século XIX à primeira metade do século XX, está ligado a imigrantes e mais raramente às elites tradicionais. Há que agregar, pelo menos durante o Império e a Primeira República, o fascínio pela burocracia eclesiástica, que fez com que filhos da elite, especialmente da fundiária, se dedicassem à carreira eclesiástica, atingindo os quadros do episcopado católico romano (MICELI, 1988).

D) A ausência de mercado financeiro mais estruturado deve ser levada em consideração. Na verdade, quando nos referimos às fontes de capital para dar sustentação à atividade empresarial, podemos imaginar que, sem mercado financeiro em que se possam colocar ações e títulos de endividamento (equity e debt), o que resta são apenas os recursos individuais ou familiares. A moderna sociedade anônima só tem sentido, quando há mercado financeiro institucionalizado capaz de absorver riscos, aproveitar oportunidades e permitir, em última instância, a fragmentação do capital com a democratização da propriedade empresarial e a ascensão de uma empresa profissionalmente gerida, ou seja, cuja propriedade e gestão estão separadas. Na ausência de tal mercado, o que aparece como sucedâneo é o Estado como fornecedor de capital e fomentador da atividade empresarial. $\mathrm{O}$ Estado desenvolvimentista em algumas nações do Terceiro Mundo do século XX se explica no vazio de um mercado financeiro criado e operado com recursos privados.

O Império brasileiro teve exíguo mercado financeiro e sempre com presença pesada do Estado. A posição do Estado neste mercado é ambivalente; de um lado pode atuar como fomentador, mas de outro pode também vê-lo como maneira de captar recursos para cobrir suas despesas, que não são inteiramente cobertas com recursos fiscais. $\mathrm{O}$ endividamento público tem no Brasil uma longa tradição, tanto no âmbito interno, como através do endividamento externo. $\mathrm{O}$ fato de não haver mercado financeiro estruturado tornava o empreendimento dependente exclusivamente da capacidade de aporte de recursos por parte de seus proprietários, limitando seriamente a capacidade de expansão. No limite, poderia fazê-lo apenas através da reinversão dos lucros gerados.

E) O quadro institucional do Império era restritivo da atividade empresarial exercida privadamente. Isto se pode deduzir do que foi apresentado até o momento, tanto pelas razões culturais, como pelo cenário político, pela atuação das elites e em virtude do próprio modelo econômico existente de tipo agrário-exportador. Retomando os principais pontos, lembraríamos a ausência de mercado interno apreciável pelo fato de a economia ser baseada em mão de obra escrava, acarretando reduzida massa 
salarial. Registre-se ainda a pouca disponibilidade de capitais, seja sob a forma de endividamento, seja de capital de risco. O Estado brasileiro sob o Império ainda não despertara para o papel desenvolvimentista que poderia exercer no crescimento e diversificação da economia. Finalmente, a questão cultural não conferia prestígio e status à atividade empresarial privada voltada ao mercado e objetivando lucros e acumulação. Uma carreira política, ou na burocracia estatal ou eclesiástica eram mais gratificantes, segundo os valores adotados pelas elites.

F) As comparações com os Estados Unidos auxiliariam a entender como o contexto institucional pode atuar para estabelecer parâmetros para a estratégia empresarial. Politicamente, os Estados Unidos é a manifestação, em terras do Novo Mundo, do Iluminismo e das tradições revolucionárias francesas. A forma republicana de governo é a única que se apresentava como possível à nova nação. Houve uma Guerra de Independência que marcou clara ruptura com a Inglaterra e que levou tempo a ser remediada. As relações especiais entre Estados Unidos e Reino Unido só se desenvolveram a partir da primeira metade do século XX. Uma república que surgiu da federação de treze colônias, que se desenvolveram através do vigor de uma sociedade civil e não pela ação da coroa britânica.

A escravidão foi severamente circunscrita nos Estados Unidos, mesmo antes da Guerra Civil. Ela acabou por se restringir aos estados do sul, onde predominava a monocultura algodoeira e não chegou ao resto do país. Os Estados Unidos é um país que se construiu ao longo do século XIX por expansão territorial em direção ao oeste e o movimento foi da sociedade civil e não do Estado. A escravidão, embora não estivesse inteiramente ausente na marcha para o oeste, não chegou a exercer o profundo impacto que teve na formação social dos estados sulistas nem remotamente semelhante ao que aconteceu em nossa sociedade.

Há ainda o fator cultural de uma sociedade tipicamente burguesa, onde o ethos aristocrático das colônias espanholas e da América Portuguesa nunca esteve presente. Nunca houve aristocracia na sociedade que lá se desenvolveu e nunca foi sentida a sua falta. Isto preparou o caminho para que lá se desenvolvesse a primeira sociedade de massas em nossa história, fato que não passou despercebido de diversos observadores europeus durante o século XIX (TOCQUEVILLE, 2003). A burguesia traz consigo a moral do trabalho, uma valorização do trabalho de preferência ao ócio, ao refinamento, ao lazer, ao domínio do gosto, próprios de uma sociedade de tipo aristocrático, o que acaba levando a que o empreendedorismo fosse traço importante no comportamento social. Os Estados Unidos estão entre as culturas mais empreendedoras do mundo, pelo menos nos tempos modernos.

Uma solução precoce da questão fundiária evitou que os espaços continentais norte-americanos se transformassem em latifúndios improdutivos. Isto levou ao desenvolvimento do farmer como ator social e econômico, e que juntamente com a expansão urbana e a circunscrição da escravidão contribuíram para que se formasse um imenso mercado interno.

Nos Estados Unidos, o sucesso nos negócios sempre atraiu muito mais e sempre foi socialmente mais deferido, reconhecido e auxiliador na obtenção de estima, prestígio e status do que carreiras ligadas à burocracia do Estado. O jacksonismo em administração pública também representa um antídoto contra a tendência, de origem continental européia, de se criar uma administrative class socialmente diferenciada e privilegiada.

A ação do Estado foi decisiva para que os Estados Unidos criassem um dos mais eficazes e persistentes modos de se fomentar uma economia, que até hoje teima em sobreviver apesar da retórica da globalização e do liberalismo: o protecionismo. Tão americano como a torta de maçã e o hambúrguer, foi a maneira encontrada logo após a independência para proteger a nascente e modesta economia das treze pequenas colônias do impacto possivelmente esmagador das potências econômicas européias, particularmente da Inglaterra.

Criaram-se barreiras alfandegárias aos produtos importados e partiu-se para um modelo, em grande medida, autárquico. O tamanho do país, seus recursos naturais aparentemente inesgotáveis, uma política de atração de imigrantes, as condições da economia mundial e o estado da tecnologia fizeram com que, ao longo de um século, as treze colônias se transformassem num país de dimensões 
continentais, que na transição do século XIX para o XX, já se apresentava como uma das maiores economias do mundo ao lado das potências européias como a Alemanha, a França e, naturalmente, a Inglaterra.

O quadro institucional norte-americano nos permite entender melhor como lá se desenvolveu uma economia capitalista de mercado, com um tipo de empresa que é a moderna sociedade anônima e como estas empresas puderam crescer, perseguindo estratégias de crescimento através de focos, escala e diversificações (CHANDLER, 1990).

Em conclusão, diferiam em muito os quadros institucionais dos Estados Unidos e do Império Brasileiro. Se, fiel a uma interpretação institucionalista, o contexto institucional norte-americano auxilia a explicação do capitalismo e a concepção de sociedade anônima que lá se desenvolveu, permanece a indagação de como um empreendedor manchesteriano e antítese do Império, do qual Mauá seria uma expressão, poderia ter-se aqui desenvolvido. Se isto ocorreu, estaríamos diante do excepcionalismo de Mauá, o que demandaria explicação à altura.

\section{ANÁLISE dAs EstratéGIAS do BARÃo}

Projetos de industrialização, quando a agricultura acenava como a vocação manifesta do país; diversificação de negócios, quando os grandes detentores de capital acreditavam em uma única empresa comercial; contratação de empregados assalariados, quando a elite brasileira esperneava contra as restrições ao tráfico negreiro impostas pelos ingleses. Essas, dentre outras iniciativas, indiscutivelmente auxiliaram a construir a imagem do Barão como empreendedor industrial e visionário, cujo comportamento divergia do pensamento vigente da época.

Com isso, não surpreende a consolidação da idéia de Mauá como empresário à frente do seu tempo e dotado de personalidade e talento singulares. De menino pobre, nascido na distante estância de Arroio Grande no vilarejo de Rio Grande, chegou ao Rio de Janeiro em 1823, para trabalhar como caixeiro numa firma comercial. Em pouco mais de vinte anos já se havia firmado como dono da primeira indústria montada no Brasil, o estaleiro Ponta da Areia.

Foi capaz de tornar-se comerciante, quando a Coroa portuguesa tinha uma política deliberada de alijar nativos na disputa de vagas para a atividade comercial. Uma vez dentro desse negócio, sua trajetória foi de sucesso, que culminou com a transferência da direção do negócio do seu último patrão para suas mãos. No entanto, ainda que tenha sido bem-sucedido em driblar esses obstáculos, na fase em que atuava no comércio, não pôde resistir aos outros que se levantaram ao longo de sua trajetória como empreendedor. Dessa maneira, o modelo político, econômico, legal e social brasileiro, juntamente com a inveja imperial de intrigas e complôs, criou um contexto institucional muito adverso à manutenção dos seus negócios e normalmente é apontado como o grande causador do declínio e da falência dos negócios de Mauá. Como Caldeira (1995) enfatiza: "Mauá não conseguira enraizar seus negócios na base fofa de um país escravista, onde o mercado era rarefeito e dependente do governo, e onde os homens de fortuna só queriam o progresso que não colocasse em risco seus privilégios".

De fato, ao contrário da sociedade da sua época, o movimento de Mauá, ao deixar o foco mercantil e passar à condição de industrial, pode até indicar que tinha algo como um projeto para o Brasil, uma visão do que deveria ser o nosso futuro. Estas concepções estariam claramente fundamentadas no modelo de industrialização inglês que conheceu e do qual se tornou admirador confesso. Mas a maneira como levou adiante tal visão mostram que era prisioneiro do contexto institucional brasileiro marcado por dependência com relação ao Estado e pelas limitações impostas por um mercado consumidor limitado pela falta de uma economia assalariada, pois o trabalho permaneceu sendo escravo até a última década do século XIX. Outra limitação era a escassez de mão de obra mais qualificada e que não fosse escrava. Imigrantes nunca chegaram ao Brasil nas mesmas quantidades que chegaram à Argentina e especialmente aos Estados Unidos. Ausência de um mercado financeiro onde 
pudesse obter recursos. Isto explica a criação de um banco e a sua transformação em empresa central do conglomerado de Mauá. Há que notar ainda a falta de uma mentalidade de investidores que não estivesse ligada a uma racionalidade mercantil, ou seja, viam a rentabilidade do capital basicamente através do mark up, ou seja, diferença entre custo da compra e o preço da venda. Atividades industriais tinham outra lógica e um ciclo e uma racionalidade nublada para os nossos investidores de mentalidade mercantil.

Na verdade, vemos que Mauá lançou-se com grande sofreguidão a empreendimentos dependentes de elevada capitalização, diríamos hoje, com elevadas barreiras de entrada sob a forma de necessidades de capital e de tecnologia, dois recursos que claramente não possuía e não controlava. Isto porque as empresas de Mauá se inserem nos serviços de utilidade pública, como ferrovias, navegação, iluminação pública e, quando se trata de pecuária, caso de seus negócios no Uruguai, dependentes de decisões governamentais. Empresas de serviços de utilidade pública ainda dependem de uma concessão governamental, que assegure algum tipo de monopólio em sua exploração. Todas estas coisas indicam que Mauá estaria bem distante do modelo de um empresário manchesteriano. De certa forma, confiava na ordem institucional do Império que lhe deveria assegurar condições para o sucesso de seus empreendimentos, o que implicava certa contradição.

Se revisarmos seus principais negócios, a partir de seu próprio texto na Exposição aos Credores e ao Público, encontramos aí boas razões para o insucesso, explicáveis a partir do que hoje conhecemos sobre estratégia empresarial.

O Estabelecimento da Ponta da Areia era um estaleiro, que teria como principal, senão exclusivo cliente, o próprio Estado. Foi formado parcialmente com recursos do próprio Mauá e o restante com recursos públicos. Havia ainda o benefício da legislação protecionista (tarifas Alves Branco) estabelecidas em 1844, e que criavam barreiras alfandegárias ao produto importado. Posteriormente estas barreiras foram alteradas e o produto nacional perdeu competitividade.

A Companhia de Iluminação a Gás do Rio de Janeiro pode ser visto como raro bom negócio, na medida em que obteve sucesso, foi lucrativa e acabou sendo vendida aos ingleses por um preço vantajoso. Novamente, estamos diante de empresa dependente de concessão do poder público. Na obtenção da concessão, Mauá mostrou-se competente lobista, pois teve acesso ao que hoje chamaríamos de informação privilegiada e acabou oferecendo uma tarifa inferior a do outro concorrente, o que lhe valeu a obtenção da concessão.

Envolvimentos na Bacia do Prata. Os negócios de Mauá no Uruguai envolviam bancos e fornecimento de carne ao exército uruguaio. Na verdade, Mauá declara ter prestado serviços ao Brasil, ao se envolver no Uruguai para deter o avanço do ditador argentino Rosas e, desta forma, salvaguardar os interesses brasileiros. Na verdade, estamos longe de um negócio que pudesse parecer atividade empreendedora sem outras conotações que não os negócios. Os interesses de Mauá e da Coroa se mesclam e isto sem que se possa dizer que ele estivesse fazendo bons negócios, como acabou sendo demonstrado com o passar do tempo.

A Estrada de Ferro de Petrópolis foi a iniciativa de Mauá, que teve o condão de torná-lo mais conhecido e também favoreceu seu registro histórico de empreendedor. Na verdade, foi seu empreendimento mais visível na época e que contribuiu para a consolidação de sua imagem de grande empresário. Mas enquanto negócio foi outro insucesso. Se olhada do ponto de vista da viabilidade, haveria que lembrar que não havia nem passageiros, nem carga suficientes para mantê-la operando. Para que tal ocorresse, seria necessário construir uma rodovia de acesso, que só foi construída tardiamente. Posteriormente, a estrada teve de sofrer com a concorrência de outra ferrovia que acabou por inviabilizá-la. Mauá recorreu ao governo, solicitando que fundos públicos fossem usados para lhe assegurar o pagamento de juros por um período de 10 anos, referentes ao capital investido na ferrovia. A prática, que não era incomum na época, mostra um quadro institucional em que o governo tinha de intervir, eliminando o risco do investimento. Trata-se de procedimento também pouco compatível com a concepção de empreendedor manchesteriano. 
A Navegação a Vapor do Rio Amazonas foi uma empresa criada por iniciativa governamental, mas que encontrou em Mauá um sócio disposto a assumir o negócio. Foi talvez um caso precoce do que hoje se chamaria uma parceria entre o governo e o setor empresarial privado. Foi um bom negócio para Mauá.

\section{As empresas Estrada de Ferro do Recife a São Francisco e a Companhia Diques Flutuantes} nunca chegaram a existir.

Outro negócio foi a Companhia de Curtumes, onde Mauá entrou como minoritário, aportando um sexto do capital. Não foi o sócio gerente. A empresa acabou sendo mal gerida e terminou por acumular enorme débito junto à empresa Mauá \& Companhia, controlada pelo Barão e que nunca foi saldado. $\mathrm{O}$ saldo foi mais um mau negócio que auxiliou na criação do passivo que faria finalmente o barão ir à falência. A esta lista de fracassos, pode-se adicionar a Companhia Luz Esteárica, semelhante ao da Companhia de Curtumes. Dívidas se acumularam e não foram nunca pagas.

Outro caso interessante é o da Montes Áureos Brazilian Gold Mining Company, que acabou se revelando nada mais do que uma falcatrua, pois as jazidas estavam totalmente esgotadas. $\mathrm{Na}$ Exposição aos Credores não fica claro como Mauá se envolveu com tal empreendimento, nem quanto teria perdido. Aparentemente, emprestou seu nome e seu prestígio para levantamento de capital na praça de Londres, mas quando uma equipe de técnicos foi proceder ao levantamento das jazidas para cuja exploração a empresa estaria sendo criada, verificou-se que as jazidas estavam esgotadas.

Finalmente, temos o caso da empresa mais longamente exposta na Exposição e que se arrastou até o final de sua vida. A viúva morreu, já no século XX, tentando receber o que, segundo Mauá, os ingleses lhe deviam. Trata-se da São Paulo Railway, ferrovia que ligava o porto de Santos ao planalto paulista, indo até a cidade de Jundiaí. A ferrovia começou a operar em 1867 e foi na época significativo feito tecnológico, pois se tratava de transpor o paredão da Serra do Mar, o que foi feito, usando-se um sistema de catracas que permaneceu em operação durante o século seguinte. A ligação se fazia necessária devido à expansão cafeeira em direção ao interior de São Paulo. O vale do Paraíba, região por onde o café entrara em São Paulo, já declinara e o Estado reconhecia no café sua grande e principal fonte de riqueza, que serviu de fundamento à posterior expansão econômica do estado de São Paulo.

Mauá entrou no negócio quando obteve a concessão para construir a ferrovia. Como o empreendimento demandava muito capital, dirige-se a Londres, o que consegue, mas a um custo de captação elevado, pois o estabelecimento inglês de Rothschild \& Sons decide cobrar caro para pôr seu nome na empresa. Tratava-se de associar alguém de prestígio internacional ao empreendimento, a fim de assegurar os demais investidores potenciais. A obra finalmente se inicia e há uma série de estouros orçamentários que levam o Barão a arcar com substanciais desembolsos para que a obra prosseguisse. Com a obra muito mais cara do que se pensara inicialmente, o Barão acabou metido em imenso imbroglio, que acabou potenciando sua falência. Houve também queixas contra o governo da província de São Paulo que decidiu construir uma rodovia com o mesmo traçado da ferrovia criando uma concorrência desleal.

No final, pode-se dizer que o caso da Santos a Jundiaí, nome pelo qual a ferrovia passou a ser conhecida durante a segunda metade do século XX, pode ter envolvido imprudência de Mauá e desonestidade e oportunismo dos ingleses. Mas do ponto de vista do Barão, o episódio em sua inteireza revelam mais uma propensão a negócios mal sucedidos.

De uma perspectiva estratégica, não causa surpresa o insucesso de Mauá. Ele seria explicável e previsível, se atentarmos para o conhecimento acumulado sobre estratégia empresarial. A nossa avaliação leva em conta o contexto institucional brasileiro, o que serve para se julgar com maior severidade as estratégias empresariais do barão.

Portanto, revisitando seus empreendimentos, podemos perceber uma estratégia de diversificação excessiva, que carecia de economias de escala e escopo: um grupo de negócios que apresentavam alta alavancagem financeira, o que parece bastante complicado, dada a precariedade do mercado financeiro 
na época. Adicionam-se ainda investimentos, cuja conotação era pesadamente política e que, no final das contas, acabaram por contribuir para o insucesso final do Barão. Outro conjunto de negócios, que morreu no próprio nascedouro, sendo a simples idéia de iniciá-los um equívoco. Finalmente, temos ainda um grupo de empresas altamente dependentes de concessão governamental, dada sua natureza de utilidade pública.

O quadro que segue coloca em forma gráfica e ilustra, ao longo do tempo, os empreendimentos até aqui relatados.

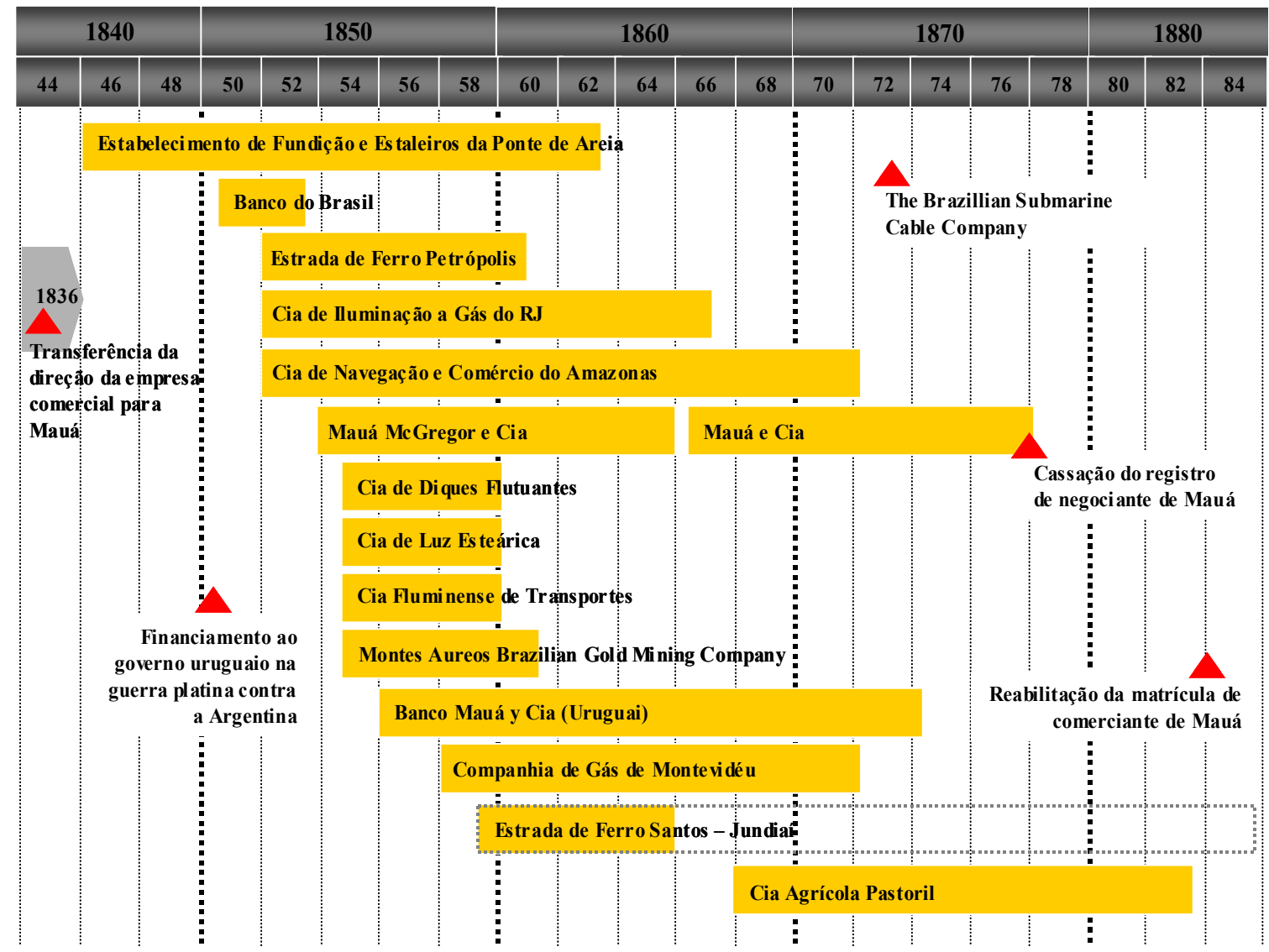

(*) Algumas empresas não estão apresentadas na figura. São elas: as estradas de ferro da Tijuca, Bahia - São Francisco e Recife - São Francisco, o Botanical Gardens Rail Road City e a Companhia de Curtumes.

O início, ou posterior sobrevivência, de um razoável conjunto de investimentos do Barão dependia do Império, em maior ou menor grau, desde concessões de exploração até financiamentos e subsídios. Assim, podemos incluir: o Estabelecimento de Fundição da Ponta de Areia, cujo maior, senão único cliente, era o próprio governo; a Companhia de Iluminação a Gás do Rio de Janeiro, concessão governamental fornecida a Mauá; de igual modo, a Companhia Fluminense de Transportes obteve permissão do Império para atuar no transportes de cargas por carroças; a Companhia da Estrada de Ferro de Petrópolis, outra concessão do governo para a exploração da área de Porto de Estrela até Petrópolis; a Companhia Navegação a Vapor do Amazonas, viabilizada pelo monopólio de navegação de 30 anos dado a Mauá, além de um subsídio anual de 120 contos de réis para colocar em funcionamento linhas de transporte, onde não havia carga para levar; e, finalmente, a já citada Estrada de Ferro Santos - Jundiaí, outra permissão do governo para a construção da ferrovia.

Com isso, o que se percebe é que a pretensa imagem de independência de Mauá parece não ter muito sentido, quando observamos esse grupo de empreendimentos, cuja história estava amarrada, de uma forma ou de outra, ao governo. No mínimo, podemos dizer que se o Império foi duro com o Barão, em 
vários momentos de sua trajetória, ele também se utilizou dele em outras tantas situações e pôde viabilizar muita das suas empresas através dos laços que nunca deixou de ter com a Coroa.

Outro fator que chama atenção nos negócios do Barão era a alta alavancagem sobre a qual eles se balizavam. Podemos até mesmo dizer que a centralidade dos bancos de Mauá nos seus negócios se devia muito ao fato de que era através deles que esse empreendedor buscava alimentar todos os seus outros empreendimentos. Isso porque, desde a criação do Banco do Brasil em 1851, passando pela concepção de seus outros bancos - Mauá McGregor e Cia (1854 - 1866) e Banco Mauá e Cia no Uruguai (1856 - 1874) - a lógica que Mauá seguia era de juntar capital de terceiros para financiar a formação de outras empresas, incluindo as suas. De fato, foi a captação de recursos do Banco do Brasil que possibilitou, em grande parte, arrecadar dinheiro para os investimentos necessários no projeto de iluminação do Rio de Janeiro e na empresa de cabotagem no Amazonas. Mesmo depois, quando o país já havia adotado uma política conservadora de restrição ao crédito, controlando as emissões de títulos bancários e aumentando os juros sobre os empréstimos, Mauá inaugurou os negócios de diques flutuantes, transportes, luz esteárica e mineração através do banco Mauá McGregor e Cia. Como Caldeira (1995) explica:

O estatuto do Banco do Brasil, por exemplo, permitia fazer empréstimo sobre uma caução de ações de empresas, inclusive do próprio banco. Com isso, assim que o dono do banco integralizou sua parte no capital, pôde empenhar ali mesmo os papéis e receber de volta quase tudo o que tinha gasto como empréstimo, duplicando o capital a sua disposição. Esse dinheiro era aplicado numa nova empresa e, assim que as ações eram recebidas, seguia o caminho da caução - deixando de novo o proprietário com capitais livres. E como a nova empresa mantinha ela própria conta no banco, se fosse preciso, ainda podia tomar mais empréstimos para financiar sua implantação. $\mathrm{O}$ ciclo, sempre repetido, gerava uma cadeia de multiplicação de capitais, inteiramente baseada no uso do dinheiro de terceiros. No fim das contas, Mauá e suas empresas deviam ao banco uma parte ponderável do capital e dos investimentos de todas elas (pág. 253).

No entanto, se os bancos tiveram papel fundamental na expansão do seu império, se tornaram a grande fragilidade dos seus negócios. Isso porque, se em dado momento houvesse uma queda nos depósitos, os bancos do Barão ficariam expostos, visto que não haveria dinheiro para pagar os investidores, uma vez que o capital estaria imobilizado em outros negócios.

Naquele tempo, os bancos tinham de conviver com a realidade de grande parte de seus depósitos exigíveis à vista e empréstimos a prazo. Com isso, a capacidade de um banco de entregar dinheiro após uma corrida de correntistas era muito limitada. E como não havia Banco Central, para socorrer com suas linhas automáticas de redesconto dos ativos em carteira nos momentos de crise, grandes corridas acabavam provocando o fechamento dos bancos, ainda que gozassem de uma situação econômica boa. E, de fato, alguns de seus bancos fecharam as portas exatamente porque não puderam agüentar corridas de correntistas, tão comuns na época. No entanto, como os bancos ocupavam posição privilegiada no império de Mauá, o fechamento de um banco debilitava fortemente o resto dos seus empreendimentos, uma vez que o colapso se dava justamente no coração do sistema empresarial montado por Mauá.

Outro ponto importante que vale a pena comentar é a natureza fortemente política de algumas de suas ações e que, no fim, acabaram por favorecer a falência do seu império. Decisão bastante ilustrativa desse tipo de negócio foi o envolvimento do Barão na questão do Prata, prestando serviços relativos aos interesses da política do governo imperial de D. Pedro II na região.

Os motivos para o governo brasileiro intervir na questão platina, apoiando o Uruguai contra a Argentina, se devia a fatores de demarcação de fronteiras e à disputa territorial. Era pelos rios da Bacia Platina (rios Paraná, Paraguai e Uruguai) que escoava quase toda a produção da Argentina, Uruguai, Paraguai e de algumas províncias brasileiras. No entanto, se as causas de D. Pedro II eram claras, as da intervenção do Barão eram um pouco mais nebulosas.

Mauá foi o financiador da guerra uruguaia em uma decisão que, podemos dizer, foge bastante do comportamento esperado de um empreendedor. Ele adentrou nessa guerra, esperando conseguir 
aproximar-se de D. Pedro II e, desse modo, colher os favores e privilégios que desfrutavam aqueles que estavam sob as asas protetoras do imperador. Novamente, o que vemos é uma postura que não condiz com a tão propalada independência e altivez do Barão em face da visão do Império brasileiro. Assim, não se pode afirmar que Mauá não agia com a mesma reverência ao governo como os comerciantes portugueses ou os fazendeiros e traficantes brasileiros. Também não podemos ratificar totalmente a idéia de Mauá como praticante ortodoxo do livre mercado e avesso aos privilégios políticos e legais, vistos como entraves ao desenvolvimento e diminuidores da eficiência de mercado.

Desse modo, caberia observar que, na articulação de seus negócios, Mauá não se portava como empreendedor de tipo clássico, voltado ao seu negócio e buscando naturalmente obter dele o maior lucro e a maior rentabilidade. Mesclava seus interesses com os interesses nacionais e certamente usou os negócios para marcar presença também no cenário político do Império, o que inegavelmente conseguiu fazer. Não esquecer que o modesto menino caixeiro tornou-se barão, integrou a assembléia nacional, circulava com desenvoltura no meio da elite política e morreu visconde. Isto fez com que mesclasse negócios com política de maneira que, muitas vezes, tem-se a impressão que a política atrapalhou os negócios. Curiosamente, dependia do quadro institucional do Império para poder viabilizar os seus negócios, quadro institucional que seria adverso a um empreendedor de tipo manchesteriano, que é a maneira como se apresenta Mauá.

Temos ainda outro grupo de negócios que poderíamos caracterizar mais como projetos de empreendimentos, uma vez que muitos deles mal chegaram a iniciar suas operações e, quando conseguiram, apenas comprovaram sua vocação para o fracasso. A Companhia Diques Flutuantes, a Companhia Luz Esteárica, a Montes Áureos Brazilian Gold Mining Company ou a Companhia Fluminense de Transportes são exemplos claros desse tipo de negócio. Grandes investimentos cujos resultados nunca foram atingidos e, no final, apenas debilitaram a saúde financeira do império do Barão.

Vale ainda sublinhar outro aspecto dos negócios de Mauá. Observando os empreendimentos que compunham seu império, podemos enxergar uma nítida estratégia de diversificação não relacionada. Esse tipo de estratégia se caracteriza por negócios que compartilham poucos, ou muitas vezes inexistentes, atributos em comum (BARNEY, 2002). Desse modo, dada a heterogeneidade do império de Mauá, vantagens tradicionalmente associadas a diversificação relacionada, tais como, economias de escala e escopo (CHANDLER, 1990 ) e sinergia (ANSOFF, 1986) não podem ser associadas aos benefícios que os múltiplos negócios do Barão poderiam angariar. Isto poderia ser explicado em função da limitação do mercado. A restrição que o trabalho escravo impunha à demanda agregada tornava o potencial de crescimento sempre reduzido. Com isso, economias advindas de menores custos de produção e contratos, bem como sinergias resultantes de compartilhamento de recursos (DAWLEY; HOFFMAN; BROCKMAN, 2003) não se aplicam à vasta gama de iniciativas de Mauá.

$\mathrm{Na}$ verdade, estratégias de diversificação não relacionada normalmente se relacionam à redução de riscos e aumento de lucratividade no longo prazo. No entanto, fazendo uma retrospectiva dos negócios de Mauá, parece-nos que ele não seguia uma lógica de mitigação de riscos na construção do portfólio dos seus negócios, mas de investir em qualquer suposta boa idéia, que lhe parecesse viável. Essa diversificação de atividades mais parecia obedecer a uma lógica de comerciante do que de industrial. $\mathrm{Na}$ verdade, a racionalidade do comércio implica vender tudo aquilo para o que se imagina existam compradores. No caso de uma transposição de tal racionalidade para o setor industrial, fabricar-se-ia tudo aquilo que pudesse ser vendido. Ora, isto abre um leque muito amplo e de difícil sustentação. Pode-se também imaginar como seria a aplicação do conceito de "cadeia de valores" (PORTER, 2003) aos negócios do Barão. Na verdade, seria problemático saber em que atividades, ou em que ponto de cada uma das atividades, se geraria valor e como o acionista se beneficiaria do valor gerado.

Por último, outro ponto importante nas operações das empresas seria o controle administrativo. $\mathrm{O}$ controle foi sempre função gerencial nevrálgica a ocupar o tempo e a demandar os talentos de administradores. Isto vai desde os rudimentos da administração chamada de científica até o moderno BSC e os Sistemas Integrados de Gestão. Fatores a dificultar o controle foram historicamente o tamanho e a dispersão geográfica. As empresas de Mauá tinham que lidar com ambas as dificuldades. 
Algumas eram grandes empreendimentos para a escala da época e se dispersavam num território de dimensões continentais, precariamente servidas por meios de transporte, e numa época em que o telégrafo ainda dava os primeiros passos, sem que possivelmente tivesse chegado a nosso país. $\mathrm{O}$ telefone só surgiu na virada do século e o primeiro cabo telegráfico submarino, conectando o Brasil à Europa, ainda não havia sido lançado. Correios não eram de grande eficiência e cobriam apenas parte do território nacional.

Assim, as atividades e os movimentos de Mauá mostram que estaríamos diante de um visionário, no sentido que esta palavra adquiriu em estratégia de negócios, mas com dificuldades em adequar sua visão às limitações inevitáveis que a realidade acaba impondo. Desta forma, Mauá parecia expor-se excessivamente ao risco, o que acabou por vitimá-lo, enquanto homem de negócios.

No texto da Exposição aos Credores, queixa-se com freqüência dos demais, sócios, parceiros ingleses, do governo imperial e de ministros de estado, usando um discurso moralista e, por vezes, acusatório. Claro que não se esperaria que o texto contivesse uma avaliação crítica de sua estratégia empresarial, mas isto não parece nunca ter preocupado o Barão. Aparentemente, morreu triste por ver que o império empresarial que tentara construir acabou fenecendo, mas com a consciência tranqüila por se considerar um homem ético e ter recuperado seu título de comerciante, depois de haver pago todos os credores. Todas estas coisas são indiscutivelmente louváveis de diversos pontos de vista, mas não servem ao propósito de resgatar a figura do empreendedor de tipo manchesteriano e o estrategista de negócios.

\section{CONCLUSÕES}

Este artigo indica a importância de considerar-se o contexto institucional para a explicação de uma determinada estratégia empresarial. Há contextos institucionais favoráveis ou desfavoráveis a certos tipos de estratégia. A questão do favorecimento do empreendimento e do sucesso econômico permite que se coloque o contexto institucional como tendo importância na explicação do desenvolvimento de algumas sociedades e também no menor desenvolvimento de outras. Igualmente o contexto institucional do Império brasileiro mostra que ele era pouco favorável ao empreendedorismo de tipo clássico como encontrado nos Estados Unidos e noutros países lideres da Revolução Industrial. A impressão difundida entre nós foi de Mauá se opondo ao contexto institucional. Teria sido um deviant e como tal punido por sua oposição e desafios à ordem institucional vigente. Isto é apenas parcialmente verdadeiro. De um lado de fato se opôs, mas também confiou e passou a depender da mesma ordem na medida em que seus negócios pressupunham o apoio do poder público e do contexto institucional. Este quadro institucional não favoreceria projeto empresarial clássico que implicava visão, assunção de risco e liberdade para empreender independentemente da intervenção do Estado. O Estado tolerado pela concepção liberal clássica é aquele que se caracteriza por manter as condições institucionais necessárias para que o empreendedor atue e nada mais.

A trajetória do Barão foi utilizada por muitos, principalmente pelos defensores da industrialização no Brasil a partir de 1920, não apenas como exemplo e legitimação da causa dos empreendedores, mas especialmente como ilustração dos graves efeitos que uma postura hostil e restritiva do governo em relação a empreendedores pode causar (BARMAN, 1981). Por outro lado vale observar que as relações de Mauá com a ordem institucional e a sociedade de seu tempo eram marcadas por notória ambivalência. Sua vida e trajetória empresarial e política indicam tratar-se de pessoa ambiciosa e propensa à mobilidade ascendente. Mas que também buscava o amparo do poder público e desejava ter, e por vezes efetivamente acabou tendo, o Estado como seu parceiro nas tarefas de fazer concessões, diluir risco e financiar empreendimentos.

Não se pode deixar de registrar quanto Mauá se equivocou como estrategista de negócios. Mesmo deixando de considerar o contexto institucional de sua época e aplicando-se às suas atividades de gestão, com os conceitos correntes que hoje temos de estratégia empresarial não é surpresa que tenha 
falido. Seu itinerário estratégico distancia-se dos empresários bem sucedidos de sua época nos contextos e países em que foram estudados. As comparações são mais fáceis com os Estados Unidos, onde a história empresarial é disciplina mais desenvolvida. A falta de foco, caracterizada pela disparidade e amplitude dos negócios, prenunciavam a impossibilidade de que se realizassem os objetivos bem apresentados por Chandler com os conceitos de scale e scope.

Acreditamos que a imagem de Mauá como ainda hoje entronizada, como um modelo precoce de grande líder empresarial e especificamente industrial é compreensível, especialmente quando o país teve um projeto nacional apoiado numa burguesia nacional empreendedora e que ocupou boa parte do século XX. Mas esta imagem é apenas parcialmente verdadeira. Não se está a desmerecer o barão, cuja excepcionalidade não pode ser negada. Deixou marca profunda e de exemplaridade para os empreendedores brasileiros. Talvez alguns, impatrioticamente, possam até lastimar que Mauá não tenha nascido na Inglaterra. Talvez lá não tivesse falido e seu sucesso continuaria através de herdeiros, empresas e sucessores até os dias atuais.

Artigo recebido em 20.07.2005. Aprovado em 21.08.2005.

\section{BibLIOGRAFIA}

ALENCASTRO, L. F. Trato dos Viventes. São Paulo: Companhia das Letras. 2000.

ANSOFF, I. Corporate Strategy. New York: Pan Macmillan. 1986.

BARMAN, R. J. Business and Government in Imperial Brazil: The Experience of Viscount Maua. Journal of Latin American Studies, v. 13, n. 2, 1981.

BARNEY, J. B. Gaining and Sustaining Competitive Advantage. 2nd ed. Upper Saddle River, NJ: Prentice Hall. 2002.

BOXER, C. R. O Império Marítimo Português. 1. ed.. São Paulo: Companhia das Letras. 2002.

CALDEIRA, J. Mauá: o Empresário do Império. 22. Reimpressão. São Paulo: Companhia das Letras. 1995.

CHANDLER, A. D. Scale and Scope: the dynamics of industrial enterprise. Boston: Belknap Press. 1990.

CUNHA, E. da. Os Sertões: a campanha de Canudos. Edição Comemorativa do Centenário. São Paulo: Atelier. (o trabalho original foi publicado em 1902).

DAWLEY, D. D.; HOFFMAN, J. J.; BROCKMAN, E. N. Do Size and Diversification Type Matter? An Examination of Post-Bankruptcy Outcomes. Journal of Managerial Issues, v. 15, n. 4, p. 413 429. 2003.

FLIGSTEIN, N. The Architecture of Markets - An Economic Sociology of 21st Century Capitalist Societies, Princeton, NJ: Princeton University Press. 2001.

FURTADO, C. Formação Econômica do Brasil. 1. ed. São Paulo: Nacional. 2003.

LUZ, N. V. A luta pela industrialização no Brasil-1808-1930. 1. ed.. São Paulo: Difusão Européia do Livro. 1961.

MAUÁ, V. de. Exposição aos Credores e ao Público. São Paulo: Expressão e Cultura. 1996. 
MICELI, S. A elite eclesiástica brasileira. 1. ed. São Paulo: Bertand Brasil. 1988.

MINTZBERG, H. Strategy Safari-A Guided Tour Through the Wilds of Strategic_Management. 1st ed. New York: The Free Press. 1998.

MOOG, C. V. Bandeirantes e pioneiros: paralelo entre duas culturas, Rio de Janeiro: Graphia. 1957.

PORTER, M. Competitive Advantage. 1st ed. New York: Simon \& Schuster. 2003.

PRADO Jr., C. História Econômica do Brasil. 1. ed. São Paulo, SP: Brasiliense. 1976.

SCHWARCZ, L. M. As barbas do imperador: Dom Pedro II, um monarca nos trópicos. 1. ed. São Paulo: Companhia das Letras. 1998.

SIMONSEN, R. História Econômica do Brasil. 1. ed. São Paulo: Nacional. 1978.

TOCQUEVILLE, A. Democracy in América. London: Penguin Classics. 2003. 